\title{
BIMBINGAN DAN KONSELING ISLAM
}

\author{
(Aplikasi Terapi Gerakan Shalat dalam Bentuk \\ Gerakan Relaksasi untuk Mengurangi Kecemasan) \\ Oleh : Ismail ${ }^{1}$ \\ $* * *$
}

\begin{abstract}
Abstrak
Tulisan ini untuk menggambarkan penerapan dan pengaruh bimbingan dan konseling melalui terapi relaksasi gerakan shalat untuk mengurangi kecemasan dalam menghadapi ujian.

Adapun Kesimpulan tulisan ini adalah sikap rileks dan santai siswa dalam menghadapi ujian merupakan salah satu faktor penentu keberhasilan. Sikap tersebut tidak menunjukkan adanya kecemasan dalam menghadapi ujian. Perasaan yang tidak menyenangkan ini umumnya menimbulkan gejala-gejala fisiologis dan gejala-gejala psikologis Terapi gerakan shalat dengan menekankan tujuh gerakan inti shalat yang kemudian dieksplor untuk merelaksasi otot kita yakni berdiri tegak, takbiratul ihram, rukuk, i tidal, sujud, duduk diantara dua sujud, dan ìtidal dilanjut salam. Hal ini terbukti dengan relaksasi otot melalui terapi gerakan shalat yang diberikan dalam penelitian ini terbukti mampu menghasilkan perubahan yang signifikan terhadap kecemasan.
\end{abstract}

Kata kunci : Bimbingan dan Konseling Islam, Terapi Gerakan Shalat, Kecemasan

\section{PENDAHULUAN}

\section{A. Latar Belakang}

Bentuk layanan bimbingan dan konseling lebih banyak menggunakan pendekatan-pendekatan yang bersifat umum dalam mengatasi masalah siswa.

\footnotetext{
${ }^{1}$ Dosen Tetap IAIM Sinjai
} 
Padahal layanan konseling berbasis pendekatan agama dapat diandalkan dalam empat bidang bimbingan konseling di sekolah dan pemecahan masalah siswa baik itu masalah pribadi, sosial, belajar dan karir.

Salah satu masalah yang sering dihadapi oleh siswa di sekolah adalah kecemasan menghadapi ujian. Kecemasan dalam menghadapi ujian karena ujian merupakan suatu proses pemeriksaan mengenai pengetahuan dan keahlian siswa sebagai akibat dari suatu proses belajarnya selama menjalani pendidikan sekaligus menjadi tolak ukur bagi keberhasilan siswa dalam menempuh proses pendidikannya selama ini. Kecemasan akan hal-hal buruk yang mungkin terjadi jika tidak lulus ujian menjadi beban mental bagi siswa. Siswa juga bisa mengalami frustasi akibat rasa malu dan bersalah dengan teman ataupun keluarga

Kondisi tersebut dapat menjadi salah satu beban psikologis bagi siswa. Jika siswa tidak mengikuti atau tidak mampu menjawab pertanyataan-pertanyaan dalam ujian maka hal tersebut tentu akan mempengaruhi prestasi belajar siswa seperti tidak naik kelas. Demikian pula halnya jika siswa terlalu memikirkan tingkat kesulitan soal yang akan dihadapi dengan tingkat kemampuan belajarnya akan dapat menyebabkan semakin tingginya tingkat kecemasan siswa dalam menghadapi ujian jika tidak diimbangi dengan kesiapan mental dan fisik dalam menghadapi ujian.

\section{B. Kerangka Teori}

\section{Bimbingan dan Konseling Islam}

Bimbingan dan konseling merupakan dua rangkaian kata yang berbeda, namun pada hakikatnya mempunyai interpretasi yang sama dimana tujuan akhirnya yaitu berusaha membantu pribadi anak bimbing agar mampu mengatasi masalahnya sendiri dan mengembangkan potensi dan kemampuannya secara optimal. Konseling dalam pelaksanaannya merupakan inti daripada bimbingan. Oleh karena itu, untuk dapat membedakan kedua kata tersebut, maka di bawah ini akan dikemukakan tentang pengertian bimbingan dan konseling. Istilah bimbingan dan konseling merupakan terjemahan dari kata "guidance" dan “counseling” dalam Bahasa Inggris. Kata "guidance” berasal dari kata dasar (to 
guide), yang artinya menuntun, mempedomani, menjadi petunjuk jalan dan mengemudikan. $^{2}$

Menurut Stoops yang dikutip oleh Ahmadi dan Ahmad dalam bukunya "Bimbingan dan Konseling di Sekolah" mengatakan bahwa:

Bimbingan adalah suatu proses yang terus-menerus dalam membantu perkembangan individu untuk mencapai kemampuannya secara maksimal dalam mengarahkan manfaat yang sebesarbesarnya, baik bagi dirinya maupun bagi masyarakat. ${ }^{3}$

Kemudian Kartono memberikan batasan pengertian bimbingan sebagai berikut:

Bimbingan adalah bantuan yang diberikan kepada individu, agar ia memahami kemampuan-kemampuan dan kelemahan-kelemahan serta mempergunakan pengetahuan tersebut secara efektif di dalam menghadapi dan mengatasi masalah-masalah hidup secara bertanggung jawab. ${ }^{4}$

Prayitno menjelaskan:

Bimbingan merupakan proses pemberian bantuan yang dilakukan oleh orang yang ahli kepada seseorang atau beberapa orang individu, baik anak-anak, remaja maupun dewasa, agar orang yang dibimbing dapat mengembangkan kemampuan dirinya sendiri dan mandiri dengan memanfaatkan kekuatan individu dan sarana yang ada dan dapat dikembangkan berdasarkan nilai-nilai yang berlaku. ${ }^{5}$

Konseling dalam Kamus Bahasa Inggris, kata "counsel” yang diartikan sebagai nasehat (to obtain counsel); anjuran (to give counsel); pembicaraan (to take counsel). Dengan demikian, konseling diartikan sebagai pemberian nasehat, pemberian anjuran, dan pembicaraan dengan bertukar pikiran. ${ }^{6}$

Pengertian konseling juga dikemukakan oleh para ahli dengan berbagai rumusan batasan konseling yang berbeda-beda, tetapi inti dan tujuannya sama.

\footnotetext{
${ }^{2}$ Umar dan Sartono. Bimbingan dan Penyuluhan. Bandung: Pustaka Setia. 2001., h.9

${ }^{3}$ Drs.H. Abu Ahmadi \& Drs. Ahmad Rohani HM., Bimbingan dan Konseling di Sekolah (Cet. I; Jakarta: PT. Rineka Cipta,1991), h. 2

4 Dra. Kartini Kartono, Bimbingan dan Dasar-dasar Pelaksanaannya (Cet.I; Jakarta: CV. Rajawali, 1985), h.99

${ }^{5}$ Prof. Dr. H. Prayitno, M. Sc. Ed. Dan Drs. Erman Amti, Dasar-dasar Bimbingan dan Konseling (Cet.I; Jakarta: PT. Rineka Cipta, 1991), h. 9

${ }^{6}$ W.S. Winkel, Bimbingan dan Konseling di Institusi Pendidikan (Cet. I; Jakarta: PT. Grasindo, 1991), h. 70
} 
Sukardi juga memberikan batasan pengertian konseling sebagai berikut: "Konseling adalah bantuan yang diberikan kepada klien (counselee) dalam memecahkan masalah-masalah secara face to face, dengan cara yang sesuai dengan keadaan klien (counselee) yang dihadapi untuk mencapai kesejahteraan hidup". 7

Setelah menguraikan beberapa defenisi bimbingan dan konseling menurut para ahli, maka penulis menggabungkan kedua kata tersebut, yaitu antara bimbingan dan konseling ditinjau dari segi Islam atau yang disebut bimbingan dan konseling Islam.

Faqih memberikan batasan bimbingan dan konseling Islam yaitu sebagai berikut adalah "proses pemberian bantuan terhadap individu agar mampu hidup selaras dengan ketentuan dan petunjuk Allah, sehingga dapat mencapai kebahagiaan hidup di dunia dan akhirat."

Pengertian bimbingan dan konseling Islam menurut Arifin adalah

Kegiatan yang dilakukan oleh seseorang dalam rangka memberikan bantuan kepada orang lain yang mengalami kesulitan-kesulitan rohaniah dalam lingkungan hidupnya agar orang tersebut mampu mengatasinya sendiri karena timbul kesadaran atau penyerahan diri terhadap kekuasaan Tuhan Yang Maha Esa, sehingga timbul pada diri pribadinya suatu cahaya harapan kebahagian hidup saat sekarang dan dimasa yang akan datang. ${ }^{9}$

\section{Terapi Gerakan Shalat}

Terapi berasal dari bahasa Inggris yang asal katanya ialah "therapy yang berarti terapi, pengobatan." Kemudian menurut Kamus Besar Bahasa Indonesia terapi berarti "usaha untuk memulihkan kesehatan orang yang sedang sakit; pengobatan penyakit; perawatan penyakit."

Didalam Kamus Ilmu-ilmu Sosial juga dikatakan therapy berarti "perlakuan atau cara-cara menyembuhkan penyakit yang diderita oleh seorang individu." Selanjutnya dalam Kamus Lengkap Psikologi kata therapy berarti

${ }^{7}$ Dewa Ketut Sukardi, Dasar-dasar Bimbingan dan Penyuluhan di Sekolah (Surabaya: Usaha Nasional, 1993), h. 105

${ }^{8}$ Aunur Rahim Faqih, Bimbingan dan Konseling dalam Islam (Cet.II; Yogyakarta: UII Press, 2001), h. 12

9 Disadur dari Jurnal Ilmu Dakwah, diterbitkan oleh Fakultas Dakwah IAIN Sunan Ampel Surabaya, Edisi 1 April 2004, h. 69 
"suatu perlakuan dan pengobatan yang ditujukan kepada penyembuhan satu kondisi patologis."

Kartono (Zanikhan, 2009) mengatakan "Terapi ialah metode penyembuhan dari gangguan-gangguan kejiwaan." Kemudian Singgih D Gunarsa (Zanikhan, 2009) merumuskan pengertian terapi sebagai berikut: Perawatan terhadap aspek kejiwaan seseorang. Dalam Oxford English Dictionary, psychotherapeutic (Zanikhan, 2009)

Terapi diartikan sebagai perawatan terhadap sesuatu penyakit dengan mempergunakan teknik psikologis untuk melakukan intervensi psikis. Dengan demikian perawatan melalui teknik psikoterapi adalah perawatan yang secara umum mempergunakan intervensi psikis dengan pendekatan psikologik terhadap pasien yang mengalami gangguan psikis atau hambatan kepribadian. ${ }^{10}$

Adapun secara etimologis shalat mengandung arti berdo'a memohon kebaikan dan pujian. Sedangkan secara hakikat mengandung pengertian berhadap hati (jiwa) kepada Allah dan mendatangkan takut kepada-Nya, serta menumbuhkan rasa keagungan, kebesaran dan kesempurnaan sang khaliq didasar jiwa. Adapun menurut pemahaman ilmu fiqih, shalat merupakan rangkaian pebuatan, dan perkataan yang dimulai dengan takbir dan diakhiri dengan salam.

Jadi dapat disimpulkan terapi gerakan shalat adalah suatu perlakuan dan pengobatan yang ditujukan kepada penyembuhan gangguan-gangguan kejiwaan dengan memadukan teknik psikologis dengan rangkaian gerakan-gerakan dalam shalat yang dimulai dengan takbir dan diakhiri dengan salam untuk melakukan intervensi psikis.

\section{Kecemasan Menghadapi Ujian}

Kecemasan atau dalam Bahasa Inggrisnya "anxiety” berasal dari Bahasa Latin “angustus” yang berarti kaku, dan "ango, anci” yang berarti mencekik.

Istilah "kecemasan" mengacu pada perasaan tidak nyaman dan ketakutan, ditambah dengan beberapa gejala fisik yang tidak menyenangkan, termasuk

10 Zanikhan. 2009. Tinjauan Umum Tentang Terapi, Puasa, dan Marah. http://zanikhan.multiply.com/journal/item/1738 (Online).hal.4 
ketegangan (otot yang menegang), denyut jantung yang bertambah cepat, nafas memburu, mulut kering, badan berkeringat dan gemetar. Apabila rasa cemas semakin parah, berbagai hal yang lebih buruk bisa muncul, misalnya rasa pusing, pingsan, dada sakit, pandangan buram, perasaan tercekik, badan terasa panas dan dingin, mual dan sering buang air atau diare. ${ }^{11}$ Kecemasan kadang-kadang dapat dianggap sebagai suatu gejala yang hampir sama dengan rasa takut, sehingga dapat mengganggu terwujudnya perilaku sehat dan keduanya dapat menimbulkan perilaku abnormal. Perasaan yang tidak menyenangkan ini umumnya menimbulkan gejala-gejala fisiologis (seperti gemetar, berkeringat, detak jantung meningkat, dan lain-lain) dan gejala-gejala psikologis (seperti panik, tegang, bingung, tak dapat berkonsentrasi, dan sebagainya).

Freud mengatakan bahwa kecemasan adalah fungsi ego untuk memperingatkan individu tentang kemungkinan datangnya suatu bahaya sehingga dapat disiapkan reaksi adaptif yang sesuai.. Kecemasan berfungsi sebagai mekanisme yang melindungi ego karena kecemasan memberi sinyal kepada kita bahwa ada bahaya dan kalau tidak dilakukan tindakan yang tepat maka bahaya itu akan meningkat sampai ego dikalahkan. ${ }^{12}$

Kecemasan adalah suatu keadaan patologis yang ditandai oleh perasaan ketakutan disertai tanda somatis terutama sistem saraf otonom yang menjadi hiperaktif (Kaplan dan Sadock, 2000). ${ }^{13}$ Kecemasan merupakan ketegangan, rasa tidak aman dan kekhawatiran yang timbul karena dirasakan akan terjadi sesuatu yang tidak menyenangkan, tetapi sumbernya sebagian besar tidak diketahui dan manifesti kecemasan dapat melibatkan somatik dan psikologis.

\section{Metode Penelitian}

Pendekatan yang digunakan dalam penelitian ini adalah pendekatan eksperimen yang bersifat kuantitatif, yang mengkaji tentang penerapan terapi gerakan shalat terhadap tingkat kecemasan siswa. Teknik pengumpulan data

\footnotetext{
${ }^{11}$ Wayne Froggatt. 2003. Free from Stres. Panduan untuk Mengatasi Kecemasan. Jakarta: PT. Buana Ilmu Populer

${ }^{12}$ Alwisol. 2006. Psikologi Kepribadian. Malang: UMM Press

${ }^{13}$ Kaplan H.I, Sadock B.J.Made W (eds). 2000. Gangguan Kecemasan dalam Sinopsis Psikiatri. Jakarta: Binarupa Aksara
} 
sangat dibutuhkan dalam penelitian, sebab dapat menentukan keberhasilan suatu penelitian. Kualitas data ditentukan oleh kualitas alat pengumpulan data yang cukup valid. Teknik pengumpulan data yang digunakan dalam penelitian ini adalah angket (kuesioner) sebagai teknik utama. Observasi dan dokumentasi sebagai teknik pelengkap

\section{PEMBAHASAN}

\section{A. Penerapan Bimbingan dan Konseling Islam}

Secara umum tujuan bimbingan dan konseling Islam adalah membantu individu mewujudkan dirinya sebagai manusia seutuhnya agar mencapai kebahagiaan hidup di dunia dan di akhirat. Sedangkan secara khusus bertujuan untuk membantu individu agar menyadari eksistensinya sebagai makhluk Allah, sehingga perilakunya tidak keluar dari aturan, ketentuan dan petunjuk Allah. (Faqih: 2001) ${ }^{14}$

Dalam konseling Islam, teori-teori yang digunakan berasal dari wahyu AlQur'an dan Sunnah Rasul, dan juga sebagai landasan pijak dalam melakukan proses konseling pada klien, agar paradigma berpikirnya, keyakinannya, potensi nuraninya, perasaannya, dan bahkan bagaimana cara-cara klien itu berinteraksi dengan lingkungannya benar-benar sesuai dengan perintah Allah dan Rasulnya.

Sebagai pedoman kepribadian konselor Islam (yang tentunya konselor muslim), Purwanto (dalam Munir) menjelaskan ciri kepribadian konselor Islam yaitu: ${ }^{15}$

1) Seorang konselor harus menjadi cermin bagi konseli.

Konselor dalam tugasnya haruslah merupakan teladan yang baik bagi konseli (klien). Klien secara psikologi datang kepada konselor karena beberapa alasan diantaranya: keyakinan bahwa diri konselor lebih arif, lebih bijaksana, lebih mengetahui permasalahan dan dapat dijadikan rujukan bagi penyelesaian masalah. Konselor merupakan teladan bagi klien, meskipun demikian tidak berarti konselor tanpa cacat.

2) Kemampuan bersimpati dan berempati yang melampaui dimensi duniawi.

\footnotetext{
${ }^{14}$ Aunur Rahim Faqih,op.cit, h. 12

${ }^{15}$ Amin Syamsul Munir. 2010. Bimbingan dan Konseling Islam. Jakarta: Amzah. h.35
} 
Seorang konselor adalah seorang yang tanggap terhadap persoalan klien. Ia dapat bersimpati pada apa yang terjadi dalam diri klien serta berempati terhadap apa yang dirasakan oleh klien. Konselor perlu mengembangkan rasa iba, kasih sayang sebatas bingkai profesi sedangkan konselor pun perlu mengembangkan semangat belas kasih yang berdimensi ukhrawi.

3) Menjadikan konseling sebagai awal keinginan bertaubat yang melegakan. Banyak kasus yang dihadapi konselor (60\%) adalah kasus yang ada kaitannya dengan pelanggaran klien terhadap kehidupan beragamanya. Bagi konselor muslim tentu akan memberikan bimbingan berdasarkan fikrah islamiah yang paling mungkin sesuai dengan derajat kasus dan derajat halal, mandub, mubah, makruh dan haram dalam konteks yang dihadapi klien.

4) Sikap menerima penghormatan: sopan santun, menghargai eksistensi.

Konselor akan selalu berhadapan dengan kenyataan bahwa klien cenderung tergantung, hormat, kagum ataupun jatuh hati pada konselor. Dalam kondisi tersebut konselor harus memberikan suatu respon yang lebih baik serta bertanggung jawab terhadap kenyataan bahwa hubungan konselor dengan klien adalah hubungan manusia.

5) Keberhasilan konseling adalah sesuatu yang baru dikehendaki.

Setiap konselor menghendaki kesuksesan dan keberhasilan. Sebagai profesi, keberhasilan konseling diukur berdasarkan berapa banyak konseli yang merasakan kepuasan pelayanan. Keberhasilan konseling adalah sesuatu yang belum pasti. Dengan demikian, ia akan bekerja keras sesuai dengan idealisme. Apabila berhasil membantu, ia tidak merasa dirinya yang berhasil, melainkan diyakini sebagai kebaikan Allah pada jerih payah konselor dan kemauan kuat klien agar keluar dari masalah yang menghimpitnya.

6) Motivasi konselor: konseling adalah suatu bentuk ibadah.

Konselor muslim hendaknya memulai segala perbuatan adalah bagian dari kebajikan hidup, bagian dari ibadah. Konseling adalah suatu upaya tausiah menghilangkan penderitaan, pembebasan manusia dari kekufuran, 
memperbaiki sifat-sifat negatif dan menjadikan klien manusia yang mendekati sempurna.

7) Konselor harus menepati moralitas Islam, kode etik, sumpah jabatan dan janji.

Konselor adalah seorang yang ahli di bidangnya dan terikat sumpah, kode etik dan juga sumpah jabatan. Konselor muslim pun demikian, ia harus berpegang teguh pada moralitas islam, sebagai seorang muslim ia pada hakikatnya telah bersumpah kepada Allah sebagai manusia terbaik dan harus menjadi yang terbaik. Ia harus teguh memegang janji yang dibuat bersama klien. Ia juga memiliki komitmen yang kuat membantu masyarakat yang luas demi kesejahteraan manusia di dunia dan di akhirat.

8) Memiliki pikiran positif (positif moralis).

Konselor selalu memiliki aliran yang diyakininya. Setiap konselor bertindak dan berpikir serta memberikan solusi sebagian besar dipengaruhi oleh cara berpikir dan nilai-nilai yang ada di dalam dirinya, serta motivasi melakukan konseling. Keyakinan ini penting karena akan mendorongnya untuk menjadi optimis terhadap setiap kebaikan dan perbaikan.

\section{B. Aplikasi Terapi Gerakan Shalat sebagai Gerak Relaksasi untuk Mengurangi Kecemasan}

Ibadah shalat sebagai salah satu perintah Allah yang paling utama untuk dikerjakan, apabila kita kaji dari segi kacamata psikologis mengandung beberapa unsur terapeutik yang tidak hanya bermanfaat dari segi jasmani saja. Akan tetapi ia turut andil berperan dalam kesehatan jiwa dan pembentukan kepribadian pada diri seorang muslim. Diantara aspek-aspek terapeutik tersebut adalah dijelaskan ${ }^{16}$ sebagai berikut :

1. Aspek olahraga

\footnotetext{
${ }^{16}$ Rika Agustina Daulay. 2002. Terapi Fisik dan Jiwa melalui Ibadah Shalat (Pengenalan aspekaspek terapeutik ibadah shalat). Jurnal : Edisi III Jumadil 'Ula 1423 H./Juli - Agustus 2002 M. Buletin Generasi HMM
} 
Gerakan shalat bisa dikategorikan sebagai olahraga karena disana juga ada gerakan fisik yang teratur dilakukan secara terus menerus dan rutin yakni 5 kali sehari, setiap hari sepanjang hidup. Maka, tidak keliru jika dalam shalat terkandung gerakan olahraga yang memiliki intensitas dan ekstensifitas lebih baik dari olahraga jenis apa pun. Bisa dibayangkan, 5 kali atau 17 rakaat dalam satu hari satu malam melakukan shalat. Itu belum dihitung dengan shalat sunnah. Dalam seminggu 7 hari, kita melakukan shalat 119 rakaat. Dalam satu bulan atau 30 hari, sebanyak 510 rakaat. Dan dalam setahun atau 365 hari kita bisa melakukan shalat sebanyak 6025 rakaat. Jika seumur hidup kita melakukan shalat maka aspek olahraga dari gerakan shalat kita akan sangat berpengaruh.

\section{Aspek relaksasi otot}

Selama kita shalat, selama itu pula berlangsungnya aktivitas relaksasi otot, yaitu kontraksi otot, pijatan dan tekanan pada bagian-bagian tubuh tertentu. Diantaranya adalah bagian kepala, leher, bahu, pergelangan tangan, jari-jari, perut, tulang belakang dan punggung, paha, pinggang, pergelangan dan jari-jari kaki. Seorang pakar mengatakan bahwa relaksasi otot ini ternyata dapat mengurangi tingkat kecemasan, imnosia (sukar tidur), hiperaktif pada anak, dan membantu mengurangi kecanduan merokok bagi para perokok yang ingin berhenti merokok.

3. Aspek meditasi

Ibadah shalat jika dilakukan dengan khusyu' dan penuh konsentrasi dapat menimbulkan aspek meditasi atau yoga. Beberapa hasil penelitian menegaskan bahwa shalat tahajjud (shalat yang dilakukan dini hari) jika dilakukan secara rutin dapat mencegah seseorang dari berbagai macam penyakit. Shalat bisa mencegah naik turunnya hormone kortisol yang berperan sebagai indicator stress, sedangkan stress merupakan pemicu timbulnya kanker. Selain itu shalat sebagai aspek meditasi dapat meningkatkan respon imun (kekebalan) tubuh terhadap penyakit.

4. Aspek relaksasi kesadaran indera

Ketika shalat, seseorang merasa seolah-olah sedang berhadapan langsung dengan Tuhannya. Ia merasa bahwa tiada lagi penghalang antara ia dan RabbNya. Segala gerakan, ucapan dan perkataan hanya ditujukan kepada Allah. Proses 
inilah yang mirip dengan proses relaksasi kesadaran indera. Relaksasi sebagai jalan menuju alam bawah sadar akan mengendalikan dan menyelaraskan fungsifungsi tubuh, seperti memompa darah keseluruh tubuh, mengendalikan pernapasan dan pencernaan.

Dari keempat aspek inilah yang sesuai dengan penjelasan tentang gerakan shalat dapat membantu merelaksasi otot dalam mengurangi reaksi fisik dan psikis yang dialami karena adanya kecemasan yang berlebihan.

Wratsongko mengemukakan tata laksana gerakan shalat beserta manfaat dari setiap gerakan tersebut disertai penjelasan manfaat dan reaksi fisik saat melakukan terapi gerakan sholat tersebut. Ada tujuh gerakan inti dalam shalat yang dikemukakan yang selanjutnya dijadikan poin untuk gerak relaksasi ${ }^{17}$ yaitu

1) Berdiri tegak

Sikap berdiri tegak dengan sikap kaki menumpu seluruh berat badan. Dalam posisi seperti ini, tubuh berada pada posisi anatomisnya. Seluruh otot, tulang dan sendi berada dalam posisi pasif sehingga menimbulkan relaksasi

2) Takbiratul ihram

Saat kedua tangan/lengan diangkat disisi kanan kiri tubuh dalam takbir, otot-otot dada akan mengembang secara pasif. Dengan mengembangnya otot-otot ini, organ paru yang ada didalamnya juga akan mengembang secara pasif mengikuti hukum tekanan negatif sehingga udara (oksigen) bisa masuk secara optimal hingga ke pembuluh paru terkecil.

Setelah itu, kedua tangan dilipat di dada sedemikian rupa sehingga pergelangan tangan kanan diletakkan diatas punggung tangan kiri serta telapak tangan kanan menggenggam pergelangan tangan kiri. Disebut bersedekap. Ditinjau dari manfaat kesehatan, sikap tangan yang terlipat diatas pusat merupakan sikap relaks atau sikap istirahat paling sempurna bagi kedua tangan.

3) Rukuk

\footnotetext{
${ }^{17}$ Madyo Wratsongko. 2010. Shalat Jadi Obat. Jakarta: PT Gramedia. hal.62
} 
Gerakan rukuk dalam shalat adalah gerakan membungkukkan punggung ke depan, kedua tangan memegang atau menempel diatas sendi lutut dan wajah menghadap ke arah tempat sujud (sajadah). Ketika posisi membungkuk disertai dengan wajah menghadap ke depan, ruas tulang belakang segmen leher sampai ekor membentuk posisi sedemikian rupa sehingga kelengkungan tiap-tiap segmen berkurang. Hal ini menyebabkan serabut serabut saraf tulang belakang mengalami relaksasi termasuk rangkaian saraf otonom (simpatik dan parasimpatik) yang berupa juluran seperti rantai disis luar (kanan-kiri) tulang belakang kita.

4) I tidal

I'tidal adalah gerakan kembali ke posisi tegak setelah rukuk. Dalam i`tidal aliran darah yang tadinya terfokus di kepala setelah rukuk akan turun ke badan sesuai gravitasi. Gerakan takbir bersamaan dengan menegakkan badan saat i tidal menyebabkan stimulus pada cabang besar saraf dibahu dan ketiak yang merupakan cabang saraf yang melayani organ jantung, paru-paru dan sebagian organ pencernaan. Selain itu, pada saat mengangkat kedua lengan, paru-paru akan mengembang sehingga dapat meningkatkan masuknya oksigen. Saat kedua lengan bergerak turun untuk berada disamping kanan dan kiri badan, sisa pembakaran atau metabolisme yang bermuatan negatif dikeluarkan bersama dengan hembusan napas.

5) Sujud

Saat melakukan sujud dibagian dahi dan kedua telapak tangan menempel di sajadah, pergelangan tangan di tekuk, kelima jari menekan sajadah. Pada posisi ini terjadi ekstensi pada ruas tulang leher, pinggang serta fleksi dibagian ruas tulang belakang segmen dada. Sementara itu, posisi pergelangan tangan yang tertekuk menyebabkan simpul saraf yang berada disekitar pergelangan tangan teregang dan terstimulasi. Pada saat kelima jari kaki tertekuk dan menekan sajadah, pergelangan kaki yang menekuk akan menyebabkan regangan simpul saraf yang berada disisi dalam dan luar pergelangan kaki (dibawah mata kaki dalam dan luar), sedangkan 
kelima jari kaki yang tertekuk serta menekan alas sajadah akan menimbulkan efek refleksi pada ujung-ujung saraf yang ada di sana.

6) Duduk diantara dua sujud

Pada posisi ini, otot-otot pangkal paha yang didalamnya ada salah satu saraf pangkal paha yang besar, yaitu diatas tumit kaki berfungsi sebagai penyangga. Gerakan ini menyebabkan otot-otot di daerah ini terpijit (refleksi). Pijatan ini bermanfaat untuk melindungi diri dari penyakit saraf pangkal paha (neuralgia) yang terasa sakit dan nyeri hingga mengakibatkan kaki tidak dapat digerakkan. Selain itu, gerakan ini akan membantu meregangkan cabang saraf tulang belakang segmen dada dan punggung bagian bawah serta pinggul. Tulang ekor sebagai tempat keluar cabang saraf juga akan meregang. Di pihak lain pada posisi ini serabut saraf pinggang ke 2 dan 3 (daerah paha sisi dalam), daerah tulang kering dan segmen ekor ke 1 (punggung kaki) akan terstimulasi (refleksi).

7) Tahiyyatul Akhir

Gerakan shalat terakhir ini terdiri atas gerakan melipat posisi kaki kiri dan kaki kanan dengan menekuk kelima jari. Dalam posisi "terkunci" ini sirkulasi energi dihentikan karena tulang punggung dibengkokkan dan pusat energi dibagian bawah antara dubur dan kemaluan ditutup dengan ujung tumit. Dengan demikian, sirkulasi energi yang mengalir dari tulang ekor menjalar ke tulang punggung dan terus masuk ke otak dan dihentikan. Dengan berhentinya sirkulasi energi, gerakan shalat pun diakhiri dengan gerakan salam, yaitu menoleh ke kanan kemudian ke kiri. Secara spiritual gerakan salam bermakna agar manusia senantiasa mengingat kebaikan (kanan) serta menjauhi keburukan (kiri) dan selalu memperhatikan lingkungan sekitar kita. Disisi kesehatan nyata, gerakan salam juga merangsang reflex di kanan kiri leher sehingga bisa mengendalikan tekanan darah dan irama jantung. Inilah bagian dari relaksasi penutup "exercise" lahir batin yang dilakukan dalam shalat. 


\section{KESIMPULAN}

Bimbingan dan konseling Islam adalah suatu usaha pemberian bantuan kepada seseorang (individu) yang mengalami kesulitan rohaniah baik mental dan spiritual agar yang bersangkutan mampu mengatasinya dengan kemampuan yang ada pada dirinya sendiri melalui dorongan dari kekuatan iman dan ketakwaan kepada Allah SWT, atau dengan kata lain bimbingan dan konseling Islam ditujukan kepada seseorang yang mengalami kesulitan, baik kesulitan lahiriah maupun batiniah yang menyangkut kehidupannya di masa kini dan masa datang agar tercapai kemampuan untuk memahami dirinya, kemampuan untuk mengarahkan dan merealisasikan dirinya sesuai dengan potensi yang dimilikinya dengan tetap berpegang pada nilai-nilai Islam.

Terapi gerakan shalat adalah suatu perlakuan dan pengobatan yang ditujukan kepada penyembuhan gangguan-gangguan kejiwaan dengan memadukan teknik psikologis dengan rangkaian gerakan-gerakan shalat yang dimulai dengan takbir dan diakhiri dengan salam untuk melakukan intervensi psikis.

Pelaksanaan terapi gerakan shalat ini dapat dipastikan mampu untuk mengatasi masalah kecemasan. Terapi gerakan shalat dengan menekankan tujuh gerakan inti shalat yang kemudian dieksplor untuk dijadikan cara untuk merelaksasi otot kita yakni berdiri tegak, takbiratul ihram, rukuk, i tidal, sujud, duduk diantara dua sujud, dan ìtidal dilanjut salam. Hal ini terbukti dengan relaksasi otot melalui terapi gerakan shalat yang diberikan dalam penelitian ini terbukti mampu menghasilkan perubahan yang signifikan terhadap kecemasan.

Berdasarkan hasil penelitian atau setelah pengenalan terapi gerakan shalat yang dilanjut dengan latihan-latihan ditemukan perbedaan sebelum dan sesudah penerapan bimbingan dan konseling Islam melalui terapi gerakan shalat. Dan yang mengindikasikan adanya pengaruh signifikan dan positif dari terapi gerakan shalat ini dalam bimbingan dan konseling yang dilakukan dan diterapkan dalam mengurangi tingkat kecemasan. 


\section{DAFTAR PUSTAKA}

Amin Syamsul Munir.. Bimbingan dan Konseling Islam. Jakarta: Amzah. 2010

Alwisol, Psikologi Kepribadian, Malang: UMM Press, 2006

Aunur Rahim Faqih, Bimbingan dan Konseling dalam Islam, Cet.II; Yogyakarta: UII Press, 2001.

Dewa Ketut Sukardi, Dasar-dasar Bimbingan dan Penyuluhan di Sekolah, Surabaya: Usaha Nasional, 1993.

Dra. Kartini Kartono, Bimbingan dan Dasar-dasar Pelaksanaannya, Cet.I; Jakarta: CV. Rajawali, 1985.

Drs.H. Abu Ahmadi \& Drs. Ahmad Rohani HM., Bimbingan dan Konseling di SekolahCet. I; Jakarta: PT. Rineka Cipta,1991.

Jurnal Ilmu Dakwah, diterbitkan oleh Fakultas Dakwah IAIN Sunan Ampel Surabaya, Edisi 1 April 2004.

Kaplan H.I, Sadock B.J.Made W (eds), Gangguan Kecemasan dalam Sinopsis Psikiatri, Jakarta: Binarupa Aksara, 2000.

Madyo Wratsongko, Shalat Jadi Obat, Jakarta: PT Gramedia, 2010

Prof. Dr. H. Prayitno, M. Sc. Ed. Dan Drs. Erman Amti, Dasar-dasar Bimbingan dan Konseling, Cet.I; Jakarta: PT. Rineka Cipta, 1991.

Rika Agustina Daulay, Terapi Fisik dan Jiwa melalui Ibadah Shalat (Pengenalan aspek-aspek terapeutik ibadah shalat), Jurnal : Edisi III Jumadil 'Ula 1423 H./Juli Agustus 2002 M, Buletin Generasi HMM, 2002.

Umar dan Sartono, Bimbingan dan Penyuluhan, Bandung: Pustaka Setia, 2001.

W.S. Winkel, Bimbingan dan Konseling di Institusi Pendidikan, Cet. I; Jakarta: PT. Grasindo, 1991.

Wayne Froggatt, Free from Stres Panduan untuk Mengatasi Kecemasan, Jakarta: PT. Buana Ilmu Populer, 2003.

Zanikhan, Tinjauan Umum Tentang Terapi, Puasa, dan Marah. http://zanikhan.multiply.com/journal/item/1738 (Online), 2009. 